\title{
Innovation in family firms: a holistic bibliometric overview of the research field
}

\author{
Gloria Aparicio ${ }^{\mathrm{a}}$, Txomin Iturralde $^{\mathrm{a}^{*}}$, Valeriano Sanchez-Famoso $^{\mathrm{a}}$ \\ ${ }^{\mathrm{a}}$ University of the Basque Country,UPV/EHU (Spain)
}

Received 4 January 2019; accepted 19 December 2019

JEL

CLASSIFICATION $M 1, M 2$

KEYWORDS

Family firms;

Innovation;

Bibliometric review

CÓDIGOS JEL

$M 1, M 2$

PALABRAS CLAVE

Empresa Familiar; Innovación;

Revisión

bibliométrica

\begin{abstract}
This paper presents a bibliometric analysis of innovation in family firms, focusing on aspects that prior literature review studies did not fully understand or evaluate. It is based on the bibliometric evaluation of 207 scientific articles published from 1994 to 2017 with innovation in family firms (IFF) as the title of the subject, keywords, and abstract. The authors discuss the results from the perspective of performance indicators and co-authorship visualization, giving a holistic bibliometric overview of the research topic. Research on IFF has emerged as an important study area, with an increasingly established position. The field has attracted researchers and has led to the development of a wide body of literature. This study provides a synthesis and organization of existing knowledge on IFF research.
\end{abstract}

Innovación en empresas familiares: una visión bibliométrica holística del campo de investigación

Resumen Este artículo presenta un análisis bibliométrico de la innovación en empresas familiares, enfocándose en aspectos que los estudios previos de revisión de literatura no entendieron o evaluaron completamente. Se basa en la evaluación bibliométrica de 207 artículos científicos publicados de 1994 a 2017 con la innovación en las empresas familiares (IEF) como título del tema, las palabras clave y el resumen. Los autores discuten los resultados desde la perspectiva de los indicadores de rendimiento y la visualización de la coautoría, dando una visión general bibliométrica holística del tema de investigación. La investigación sobre IEF ha surgido como un área de estudio importante, con una posición cada vez más establecida. El campo ha atraído a investigadores y ha llevado al desarrollo de un amplio cuerpo de literatura. Este estudio proporciona una síntesis y organización del conocimiento existente sobre la investigación de IEF.

Copyright 2019: Gloria Aparicio, Txomin Iturralde, Valeriano Sánchez-Famoso.

European Journal of Family Business is an open access journal published in Malaga by UMA Editorial. ISSN 2444-8788 ISSN-e 2444-877X This work is licensed under a Creative Commons Atribution-NonCommercial-ShareAlike 4.0 International License (CC BY-NC-SA 4.0).

Acknowledgements

Funding for this research was provided by the Spanish Ministry of Science, Innovation \& Universities (MCIU/AEI/FEDER-UE) under the Grant Number RTI2018-097579-B-100, by UPV/EHU under the Grant Number GIU16/46, by DFB/BFA and by FESIDE. 


\section{Introduction}

Research interest in family firms has increased significantly over the last decade (Debicki, Matherne, Kellermanns, \& Chrisman, 2009). This can be attributed partly to the fact that familyowned firms are the oldest form of business organizations (Gersick, Davis, Hampton, \& Lansberg, 1997), and the fact that such type of business organizations continue to hold key positions in all economies worldwide (Credit Suisse, 2018; PwC, 2018).

Scholars focusing on family firms have been interested in understanding the distinctive and idiosyncratic characteristics of family firmsexamining such firms based on two strategic theories: resource-based view (RBV) (Wernerfelt, 1995) and agency theory (AT) (Schulze, Lubatkin, Dino, \& Buchholtz, 2001; Schulze, Lubatkin, \& Dino, 2003). Both of these approaches combined with maintaining family control can influence behavior on innovation in family firms (IFF) (Chrisman, Chua, \& Steier, 2005). Nevertheless, research on family business has shifted such that scholars now consider behavioral theories, which highlight that IFF is motivated by non-financial objectives (Miller \& Le-Breton-Miller, 2014) such as socio-emotional wealth (SEW) (Gomez-Mejia, Hayes, Nunez-Nickel, Jacobson, \& MonavoFuentes, 2007) and social capital (SC) (Arregle, Hitt, Sirmon, \& Very, 2007; Gedajlovic \& Carney, 2010; Pearson, Carr, \& Shaw, 2008). Behavioral theories imply that resources are difficult to duplicate (Zahra, Hayton, \& Salvato, 2004). In line with this, the concept of "familiness" and family culture may create an environment of trust and shared goals (Dibrell \& Moeller, 2011), which can be a possible source of competitive advantage.

On the one hand, it is widely recognized in research on family firms that the first goal of family firms is to pass on the company to the next generation (e.g., Sanchez-Famoso, Maseda, \& Iturralde, 2014; Sharma, 2004; Sirmon, Arregle, Hitt, \& Webb, 2008). On the other hand, it is a common practice in the majority of family firms for the family to maintain control over the company (Chirico \& Salvato, 2016; Cruz \& Nordqvist, 2012) through either ownership (Sanchez-Famoso, Akhter, Iturralde, Chirico, \& Maseda, 2015) and/or management (D'Amato, 2017; Nordqvist \& Melin, 2010; Sanchez-Famoso, Maseda, \& Iturralde, 2017). As a result, a family firm will have more than one generation in both ownership and management positions (Drakopoulou Dodd, Anderson, \& Jack, 2013; Craig \& Dibrell, 2006; Llach \& Nordqvist, 2010). These singularities of the vast majority family firms are viewed as positive aspects for accomplishing IFF. However, there are some negative effects that constrain IFF including their conservative posture (Gilinsky, Santini, Lazzeretti, \& Eyler, 2008; Habbershon, Williams,
\& MacMillan, 2003), risk aversion (De Massis, Sharma, Chua, \& Chrisman, 2012), and limited propensity to invest capital in innovation projects (Block, 2010). These relationships are more complex and multidimensional than predicted. Therefore, there is limited current understanding on the topic of IFF and new research seems necessary.

To advance scientific knowledge, researchers generally emphasize the importance of classifying the literature of a research area based on the main trends in the discipline (Bjork, Offer, \& Söderberg, 2014). A review of literature engages researchers and practitioners not only by providing a transparent audit trail for legitimizing the order and flow of articles but also by highlighting and updating the landscape. A systematic literature review on IFF already exists. For instance, De Massis, Frattini, and Lichtenthaler (2013) focused on technological innovation. The review by Feranita, Kotlar, and De Massis (2017) contributes to the research on IFF from the perspective of collaborative innovation. More recently, Calabro, Vecchiarini, Gast, Campopiano, De Massi \& Kraus (2018) intend to expand the existing understanding of IFF through the construction of a theoretical bridge that includes organizational innovation and a business model. Despite the important contributions made by these literature reviews, the increasing development of computer technology, Internet, and bibliographic electronic databases is what allows for the incorporation of a bibliometric perspective (Baier-Fuentes, Merigó, Amoros, \& Gaviria-Marin, 2018; Cobo, Martínez, Gutiérrez-Salcedo, Fujita, \& Herrera-Viedma, 2015) in the bibliographic literature review for an in depth understanding of the research area. Bibliometric methods offer systematized and repeatable processes that can help to understand the dissemination of knowledge in a field, while highlighting gaps and opportunities that can help advancements in the field, and also provide objective criteria for assessing research development in a field and represent an important and valuable tool for evaluating scholarship quality and productivity (Cobo et al., 2015)

Thus, the present study aims to add this bibliometric perspective to research on IFF. This provides a synthesis and organization of existing knowledge. First, using performance analysis and, in particular, certain productivity and impact indicators, it is possible to highlight and provide an update on an overview of the research on IFF, revealing patterns in journals, articles, and authors. Second, establishing a network among scholars helps to detect which of them are collaborating in the publications. Third, with a deeper reading of the articles in each group of publications resulting from coauthorship analysis, the authors identify some 
areas of research that have been developed by the most prolific scholars in the area.

\section{Methodology}

Bibliometrics can be defined as a part of scientometrics that utilizes mathematical and statistical methods to study and analyze the scientific activity in a research field (Callon, Courtial, \& Laville, 1991). Bibliometric analysis provides objective criteria for evaluating development in a research field, and the technique's importance in assessing academic quality and productivity is increasing (MurgadoArmenteros, Gutiérrez-Salcedo, Torres-Ruiz, \& Cobo, 2015). Bibliometric methods have two main uses: performance analysis and science mapping (Cobo, López-Herrera, Herrera-Viedma, \& Herrera, 2011). Performance analysis seeks to evaluate the research and publications of individuals and institutions. Science mapping aims to reveal the structure and dynamics of scientific fields (Zupic \& Carter, 2015). Therefore, bibliometrics contribute to the advancement of science in several ways, such as recognizing the most relevant scientific publications and productive authors, establishing the most cited studies and identifying key themes in the field, and generating indicators of scientific production. This general methodological approach is adapted for the purpose of this study. Thus, to identify some lines of research that have been developed by the most productive researchers in the area, we conduct science mapping based on co-authorship analysis. The methodological design used for this bibliometric review has been developed in a sequential process. First, to begin the study, it is necessary to adopt a systematic search of articles, as this involves the selection of source document. Second, it is important to show the evolution of the number of publications per year in the area because it is the starting point to place the ascent interest of the topic in the scholarship. Third, to show the journals, authors and articles with maximum influence (citations) and contribution (production) in the area, we use performance analysis. This double view to measure the importance of the research allows us to make an important reflection that helps to conduct the final part of the article, that is, coauthorship analysis. This final analysis is focused on the most productive groups of authors that allow for the identification of main research trends.

\section{Selection of source document}

The first step in a bibliometric analysis is to create a database of articles for conducting the analysis. There are several sources for accessing data, including Web of Science (WoS), Scopus, and Google Scholar. The scope of the various databases of scientific documents is different since they do not cover journals in the same way. The present study only considers bibliographic records obtained from WoS. The authors use this database because it provides a set of metadata that are essential for this type of analysis, including abstracts, references, number of citations, lists of authors, institutions, countries, and the journal impact factor (Carvalho, Fleury, \& Lopes, 2013).

To conduct the analysis, we considered articles covering a period of 24 years, that is, from 1994 to 2017 (retrieved on September 3, 2018). We selected 1994 as the starting year because the first paper on IFF with the search combination terms is that of Souder and Thomas (1994). We know that prior to 1994 there were some articles of interest on the topic (Calabro et al., 2018), but these previously published articles do not appear in the systematic search. First, the selection of articles related to IFF was conducted using a combination of key terms such as ("Innovate*") AND ("family business*" OR "family firm $^{* "}$ OR "family enterprise*" OR "family influence $^{* "}$ OR "family owned ${ }^{* "}$ OR "family controlled" ${ }^{*}$ OR "family SME*" OR "family involvement") in the topic tab (including titles, Author Keywords, and abstracts of the bibliographic references) of the WoS

Subsequently, documents from WoS were processed following limitations such as: (1) corpus of the research document was restricted to "articles" and "reviews"; and (2) documents included in the categories "business" or "management" on the WoS. Using such search criteria, we obtained 207 articles that formed the resource for our bibliometric study.

\section{IFF in the Family Firm Scholarship}

The interest of a research topic can be evidenced from two complementary perspectives. First, reflecting the number of published papers and their evolution over time (the most common perspective of a bibliometric performance analysis). Second, considering the relative importance of the topic in a global framework, a family firm is the general reference of scholarship in this case.

Figure 1 shows the evolution of the literature on family firms, on IFF, and the proportion of articles on IFF within the total family firm 
research area. We observe that research on IFF is evolving and this development is even more significant on the total number of family firms that are within the scope of this research area. Therefore, the topic of innovation in family business is being consolidated.

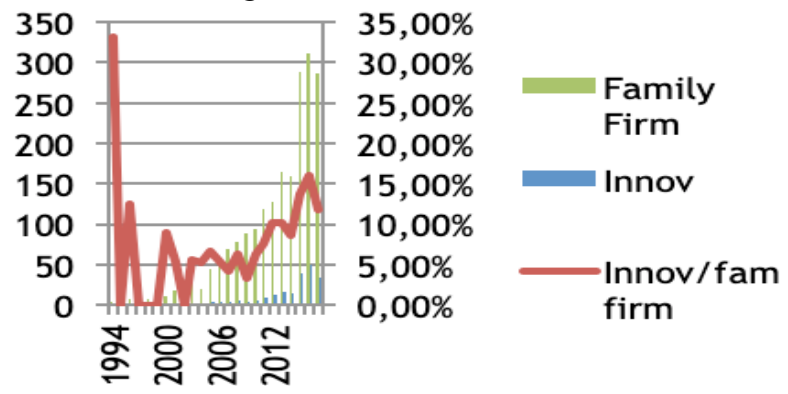

Figure 1 Evolution of scientific research on IFF.

Table 1 presents the number of articles per year (TP) and the total number of citations (TC) obtained for them, considering the citation thresholds of 150,100,50,20,10and 1. Based on the number of articles per year on IFF, the evolution of the field of study shows that the subject area's overall tendency has been ascendant, especially since 2009 . Therefore, it is possible to distinguish two periods: the initial period before 2009 (T1) and the expansion period after 2009 (T2). The dates indicate that in the initial period (1994 -2009) only 24 articles had been published, while in the expansion period (2010-2017) there were nearly 183 publications, with 124 belonging to the last three years (70\% of the expansion period). All these indicators reinforce that research on IFF is attracting increasing interest among scholars, considering the number of articles. Further, Table 1 will be analyzed in the next section for the most influential articles, because three articles with more than 150 citations and three others with more than 100 citations could be reference articles on the topic. Nearly $25 \%$ of the studies did not receive any citations with most of them falling in the latest period.

\section{Most Influential Journals, Authors and Articles IFF.}

This section presents and ranks some indicators on the influence of journals, authors, and articles, based on the information found in WoS. There are two methods to analyze the influence, counting the number of papers published and the number of citations received (Merigo \& Yang, 2017). The present article implemented a combined method to measure the importance of research on IFF. It allows making an important reflection that conducts the final part of the article where the conceptual structure of the subject area IFF is analyzed through the main research group of authors in the field.
Most influential journals

Articles on IFF are published in a wide range of journals. This field has progressed remarkably and has a wide structure of academic resources. Table 2 shows the ranking of the 29 most productive and influential journals in the field of IFF.

\begin{tabular}{|c|c|c|c|c|c|c|c|c|}
\hline YEAR & TP & TC & $>=150$ & $>=100$ & $>=50$ & $>=20$ & $>=10$ & $>=1$ \\
\hline \multicolumn{9}{|c|}{ Initial period (T1) } \\
\hline 1994 & 1 & 5 & 0 & 0 & 0 & 0 & 0 & 1 \\
\hline 1995 & 0 & 0 & 0 & 0 & 0 & 0 & 0 & 0 \\
\hline 1996 & 1 & 108 & 0 & 1 & 1 & 1 & 1 & 1 \\
\hline 1997 & 0 & 0 & 0 & 0 & 0 & 0 & 0 & 0 \\
\hline 1998 & 0 & 0 & 0 & 0 & 0 & 0 & 0 & 0 \\
\hline 1999 & 0 & 0 & 0 & 0 & 0 & 0 & 0 & 0 \\
\hline 2000 & 1 & 0 & 0 & 0 & 0 & 0 & 0 & 0 \\
\hline 2001 & 1 & 73 & 0 & 0 & 1 & 1 & 1 & 1 \\
\hline 2002 & 0 & 0 & 0 & 0 & 0 & 0 & 0 & 0 \\
\hline 2003 & 2 & 10 & 0 & 0 & 0 & 0 & 0 & 2 \\
\hline 2004 & 1 & 84 & 0 & 0 & 1 & 1 & 1 & 1 \\
\hline 2005 & 3 & 442 & 1 & 2 & 2 & 3 & 3 & 3 \\
\hline 2006 & 3 & 191 & 0 & 0 & 2 & 3 & 3 & 3 \\
\hline 2007 & 3 & 403 & 1 & 1 & 2 & 3 & 3 & 3 \\
\hline 2008 & 5 & 305 & 1 & 2 & 2 & 2 & 5 & 5 \\
\hline 2009 & 3 & 115 & 0 & 0 & 1 & 2 & 2 & 3 \\
\hline \multicolumn{9}{|c|}{ Expansion Period (T2) } \\
\hline 2010 & 6 & 220 & 0 & 0 & 1 & 4 & 5 & 6 \\
\hline 2011 & 9 & 252 & 0 & 1 & 1 & 4 & 5 & 8 \\
\hline 2012 & 13 & 515 & 0 & 1 & 4 & 8 & 10 & 13 \\
\hline 2013 & 17 & 366 & 0 & 0 & 1 & 7 & 13 & 16 \\
\hline 2014 & 14 & 238 & 0 & 0 & 1 & 4 & 10 & 14 \\
\hline 2015 & 40 & 377 & 0 & 0 & 1 & 5 & 14 & 36 \\
\hline 2016 & 50 & 110 & 0 & 0 & 0 & 1 & 3 & 31 \\
\hline 2017 & 34 & 19 & 0 & 0 & 0 & 0 & 0 & 10 \\
\hline TOTAL & 207 & 3833 & 3 & 8 & 21 & 49 & 79 & 157 \\
\hline$\%$ over TC & & & $1,45 \%$ & $3,86 \%$ & $10,14 \%$ & $23,67 \%$ & $38,16 \%$ & $75,85 \%$ \\
\hline
\end{tabular}

Specifically, Table 2 shows journals with three or more articles on IFF, as well as those with only one or two articles but with more than 50 or 20 citations, respectively. In addition, some bibliometric indicators, such as the total number of IFF papers (TP), total number of citations (TC), and the ratio of TC/TP are presented. Further, we have included articles with more than $150,100,50,10$ citations, and even a single citation. Finally, Table 2 shows the number of articles in each period, that is, $\mathrm{T} 1$ and $\mathrm{T} 2$, and the 2017 impact factors of the journals.

According to Table 2, it is observed that the most influential journals researching IFF, considering the number of articles published, are two journals with specific topics on family firms, namely Family Business Review and Journal of Family Business Strategy. It is necessary to note that if we consider the expansion period (T2), Journal of Family business Strategy publishes a greater number of articles. Table 2 also highlights the importance Journal of Product Innovation Management gives to research on IFF, since this journal published eight articles on the topic during the expansion period. 
Table 2 Most influential journals in IFF.

\begin{tabular}{|c|c|c|c|c|c|c|c|c|c|c|c|c|c|}
\hline $\mathrm{R}$ & JOURNAL & TP & $\mathrm{TC}$ & $\mathrm{TC} / \mathrm{TP}$ & $>=150$ & $>=100$ & $>=50$ & $>=20$ & $>=10$ & $>=1$ & T1 & $\mathrm{T} 2$ & \\
\hline 1 & FBR & 18 & 1119 & 62,17 & 2 & 2 & 6 & 12 & 14 & 18 & 6 & 12 & 3,82 \\
\hline 2 & JFBS & 15 & 81 & 5,40 & 0 & 0 & 0 & 1 & 3 & 12 & 0 & 15 & 2,61 \\
\hline 3 & SBE & 12 & 298 & 24,83 & 0 & 0 & 3 & 4 & 6 & 9 & 2 & 10 & 2,86 \\
\hline 4 & JPIM & 9 & 195 & 21,67 & 0 & 0 & 0 & 4 & 8 & 9 & 1 & 8 & 4,31 \\
\hline 5 & $J B R$ & 9 & 93 & 10,33 & 0 & 0 & 0 & 1 & 3 & 8 & 2 & 7 & 2,51 \\
\hline 6 & ETP & 7 & 298 & 42,57 & 0 & 2 & 2 & 4 & 5 & 7 & 2 & 5 & 5,32 \\
\hline 7 & APJM & 7 & 65 & 9,29 & 0 & 0 & 0 & 2 & 3 & 6 & 0 & 7 & 2,47 \\
\hline 8 & JSBM & 6 & 169 & 28,17 & 0 & 0 & 2 & 3 & 3 & 5 & 1 & 5 & 3,25 \\
\hline 9 & ALA & 6 & 1 & 0,17 & 0 & 0 & 0 & 0 & 0 & 1 & 0 & 6 & 0,62 \\
\hline 10 & CMR & 5 & 30 & 6,00 & 0 & 0 & 0 & 0 & 2 & 5 & 0 & 5 & 3,30 \\
\hline 11 & EJIM & 5 & 8 & 1,60 & 0 & 0 & 0 & 0 & 0 & 4 & 0 & 5 & 0,67 \\
\hline 12 & JFBM & 5 & 6 & 1,20 & 0 & 0 & 0 & 0 & 0 & 3 & 0 & 5 & $\cdots$ \\
\hline 13 & JBE & 4 & 85 & 21,25 & 0 & 0 & 0 & 2 & 2 & 4 & 0 & 4 & 2,92 \\
\hline 14 & IJEBR & 4 & 40 & 10,00 & 0 & 0 & 0 & 1 & 1 & 4 & 0 & 4 & 1,19 \\
\hline 15 & RIBS & 4 & 3 & 0,75 & 0 & 0 & 0 & 0 & 0 & 1 & 0 & 4 & $\cdots$ \\
\hline 16 & JBV & 3 & 320 & 106,67 & 0 & 2 & 3 & 3 & 3 & 3 & 1 & 2 & 6,00 \\
\hline 17 & CGIR & 3 & 42 & 14,00 & 0 & 0 & 0 & 0 & 3 & 3 & 1 & 2 & 2,75 \\
\hline 18 & $\mathrm{BH}$ & 3 & 21 & 7,00 & 0 & 0 & 0 & 0 & 1 & 3 & 1 & 2 & 1,08 \\
\hline 19 & $M D$ & 3 & 9 & 3,00 & 0 & 0 & 0 & 0 & 0 & 2 & 0 & 3 & 1,53 \\
\hline 20 & IEAMJ & 3 & 6 & 2,00 & 0 & 0 & 0 & 0 & 0 & 2 & 0 & 3 & 2,41 \\
\hline 21 & IJIM & 3 & 1 & 0,33 & 0 & 0 & 0 & 0 & 0 & 1 & 0 & 3 & -- \\
\hline 22 & ERD & 2 & 140 & 70,00 & 0 & 0 & 1 & 2 & 2 & 2 & 0 & 2 & 2,79 \\
\hline 23 & MIR & 2 & 36 & 18,00 & 0 & 0 & 0 & 0 & 2 & 2 & 1 & 1 & 2,28 \\
\hline 24 & JMO & 2 & 35 & 17,50 & 0 & 0 & 0 & 1 & 1 & 2 & 1 & 1 & 1,19 \\
\hline 25 & RMS & 2 & 23 & 11,50 & 0 & 0 & 0 & 1 & 1 & 2 & 0 & 2 & 1,48 \\
\hline 36 & JMS & 1 & 163 & 163,00 & 1 & 1 & 1 & 1 & 1 & 1 & 1 & 0 & 5,33 \\
\hline 37 & IMM & 1 & 131 & 131,00 & 0 & 1 & 1 & 1 & 1 & 1 & 1 & 0 & 3,68 \\
\hline 38 & $\mathrm{JCR}$ & 1 & 84 & 84,00 & 0 & 0 & 1 & 1 & 1 & 1 & 1 & 0 & 3,54 \\
\hline 39 & SMJ & 1 & 55 & 55,00 & 0 & 0 & 1 & 1 & 1 & 1 & 0 & 1 & 5,48 \\
\hline
\end{tabular}

Note: R: rank; TP and TC: total papers and cites, TC/TP cites per article. IF: Impact Factor. ; >= 150, >=100, >=50, >= 20, >=10, $>$ idelsol@iefamiliar.comidelsol@iefamiliar.com=1,= number of papers with 150, 100, 50, 0, 10 and 1 o more citations. T1,The first initial period before 2009, T2 the expansion period after that year. FBR, Family Business Review; JFBS, Journal of Family Business Strategy; SBE, Small Business Economics; JPIM, Journal of Product Innovation Management; JBR, Journal of Business Research; ETP, Entrepreneurship Theory and Practice; APJM, Asia Pacific Journal of Management; JSBM, Journal of Small Business Management; ALA, Academia-Revista Latinoamericana de Administracion; CMR, California Management Review; EJIM, European Journal of International Management; JFBM, Journal of Family Business Management; JBE, Journal of Business Ethics; IJEBR, International Journal of Entrepreneurial Behaviour \& Research; RIBS, Review of International Business and Strategy; JBV, Journal of Business Venturing; CGIR, Corporate Governance-An International Review; BH, Business History; MD, Management Decision; IEAMJ, International Entrepreneurship and Management Journal; IJIM, International Journal of Innovation Management; ERD, Entrepreneurship and Regional Development; MIR, Management International Review; JMO, Journal of Management \& Organization; JMS, Journal of Management Studies; IMM, Industrial Marketing Management; JCR, Journal of Consumer Research; SMJ, Strategic Management Journal; AMR, Academy of Management Rev

Another important aspect to consider in this section is the analysis on the total number of citations on IFF. Family Business Review stands out for having the largest number of TCs with 1119 citations, followed by Journal of Business Venturing, Small Business Economics and Entrepreneurship, Theory and Practice, with 320,298 , and 298 citations, respectively. Subsequently there is a third group of journals such as Journal of Product Innovation Management, Journal of Small Business Management, Entrepreneurship and Regional
Development, Journal of Management Studies, and Industrial Marketing Management, which have more than 100 citations. If we analyze the average number of citations per article, those published in Journal of Management Studies are highlighted for their 163 citations; articles published in Industrial Marketing Management with 131 citations, and three published in Journal of Business Venturing with more than 100 citations per article on average. Several factors explain this marked difference between the groups of journals (Baier-Fuentes et al., 
2018). The first factor is the overall quality of the journals. Note that most of the journals with a high number of IFF citations have a high impact factor (IF) and are well recognized in their respective fields. A second factor could be the orientation of the journals. For example, all the journals presented in Table 2 have a TC indicator that is greater than 100 and a strong orientation for publishing articles that are related to innovation in companies, research on family firms, or those that have featured issues on management, entrepreneurship, and/or small businesses.

From Table 2, it is interesting to analyze the progress of IFF research in journals. The numbers of papers published are grouped into two periods: $\mathrm{T} 1$ and $\mathrm{T} 2$. In T1, six articles were published in Family Business Review, two articles each in Small Business Economics, Journal of Business Research and Entrepreneurship Theory and Practice, and one article in ten other journals. Later, we will examine (see Table 3) the articles published in $\mathrm{T} 1$ with greater impact. Finally, from a general perspective, the results show that research on IFF has been progressively published in higher number of journals. Specifically, in T1 the 24 articles were published in 16 journals, while the 183 articles published in T2 did so in 75 journals. In T2 a wide variety of journals from covering business and management areas published IFF-based articles to explain their phenomena of study.

\section{Most cited articles}

The number of citations of an article reflects the influence, popularity, and attention received from the scientific community. In this section, we analyze the most-cited articles in journals covering business and management areas in WoS. Table 3 shows the articles with more than 50 citations in WoS -total cites (TC), considering only the citations of the 207 articles (TCIFF), and the citations per article (TC/TP)-.

The three most influential articles of the initial period have a significant number of citations (less than 284 and above 163). These citations have accumulated over more than ten years (2005-2017), so the average number of citations is more than 10 or 20 per year. It is most likely that this is not a high volume of citations per article and year, compared to other more established areas; but considering that prior to 2005 there were only seven articles on this topic, it is certain that most of the 200 papers between 2005-2017 frequently cited these three articles. Furthermore, Zhara (2005) is clearly the reference article based on the highest number of citations in WoS (284) and among papers published in the IFF dataset. Analyzing the research areas of this most cited, it is worth mentioning that all these articles have a common interest in innovation, analyzing it from an organizational point of view, instead of technical or product innovation. Zahra (2005) focuses on the influence of family ownership and CEO founders in promoting entrepreneurship and selective venturing into new market domains. Naldi, Nordqvist, Sjöberg, \& Wiklund (2007), the second most referenced article from the dataset's articles (45 citations), follows the same focus of research and addresses a comparison between family and nonfamily firms for their risk-taking tendency, and the relationship between proactiveness, innovativeness, and impact on firm performance. Eddleston, Kellermanns, \& Sarathy (2008) show that strategic planning is more important for family firms that lack (technical) innovative capacities. Finally, in $\mathrm{T} 2$ it is important to highlight Chua, Chrisman, Steier, \& Rau (2012) article, as it contributes to a better understanding of the heterogeneity of family firms by examining how vision and goals, as well as the discretion engendered by family control, influence various competitive strategies, and specifically innovation.

\section{Most productive and cited authors}

The field of IFF is characterized by continuous growth and the participation of a large number of authors. The results indicate that 455 authors contributed toward publishing 207 documents on IFF research, which is an average of 2.20 authors per article. The fact that only 12 authors have published more than three articles indicates that concentration in the field is not high. It is also noteworthy that $85.5 \% \quad(389 / 455$ authors $)$ published only one article. It is a common result because, as mentioned above, it is a relatively new area of research with growing number of publications that has not yet reached maturity.

To obtain a broader view of IFF research, authors with greater presence and influence, as well as temporal evolution of publications in the field, are determined.

Table 4 illustrates 25 authors who have published three or more papers; 9 authors with two papers but with more than 50 cited; and 9 authors with one paper but with more than 100 cited.

Note that the authors are ordered decreasingly according to their productivity in the field (TP). In the case of a tie, we considered the total number of citations in the field (TC). Furthermore, Table 4 shows TC and TP of each author per period, that is, initial period (T1) and expansion period (T2). 
Table 3 List of most cited papers.

R Title

1 Entrepreneurial risk taking in family firms

2 Entrepreneurial orientation, risk taking, and performance in family firms

3 Resource configuration in family firms: Linking resources, strategic planning and technological opportunities to performance

4 Innovativeness among small businesses: Theory and propositions for future research

5 Should I stay or should I go? Career choice intentions of students with family business background

6 Sources of Heterogeneity in Family Firms: An Introduction

7 Industry characteristics and

internationalization processes in small firms

8 The Role of Family Influence in Firms' Strategic Responses to Threat of Imitation

9 R\&D investments in family and founder firms: An agency perspective

10 Corporate governance and strategic change in SMEs: The effects of ownership, board composition and top management teams

11 Long-term orientation: Implications for the entrepreneurial orientation and performance of family businesses

12 Research on Technological Innovation in Family Firms: Present Debates and Future Directions

13 Families and innovative consumer behavior: A triadic analysis of sibling and parental influence

14 The natural environment, innovation, and firm performance: A comparative study

15 A 10-year longitudinal investigation of strategy, systems, and environment on innovation in family firms

16 Family Firms and Entrepreneurial Orientation in Publicly Traded Firms A Comparative Analysis of the S\&P 500

17 Strategic goals and practices of innovative family businesses

18 Innovativeness in family firms: a family influence perspective family firms

20 Product Innovation in Family versus Nonfamily Firms: An Exploratory Analysis

21 Risk abatement as a strategy for R\&D investments in family firms

22 The relationship between entrepreneurial orientation and growth: The moderating role of family involvement

23 The Impact of Family Involvement on the R\&D Intensity of Publicly Traded Firms

24 Family business performance: The effects of gender and management

25 Corporate Social Performance and Innovation with High Social Benefits: A Quantitative Analysis

26 The family innovator's dilemma: how family influence affects the adoption of discontinuous technologies by incumbent firms

27 Charting the Future of Family Business Research: Perspectives From the Field

28 Technology Acquisition in Family and Nonfamily Firms: A Longitudinal Analysis of Spanish Manufacturing Firms

29 The Ability and Willingness Paradox in Family Firm Innovation
19 Entrepreneurial orientation in long-lived
Authors

Zahra, SA

Naldi, Lucia; Nordqvist, Mattias;

Sjoberg, Karin; Wiklund, Johan

Eddleston, Kimberly A.; Kellermanns,

Franz Willi; Sarathy, Ravi

Hausman, A

Zellweger, Thomas; Sieger, Philipp; Halter, Frank

Chua, Jess H.; Chrisman, James J.; Steier, Lloyd P.; Rau, Sabine B.

Boter, $\mathrm{H}$; Holmquist, $\mathrm{C}$

Sirmon, David G.; Arregle, Jean-Luc; Hitt, Michael A.; Webb, Justin W.

Block, Joern $\mathrm{H}$.

Brunninge, Olof; Nordqvist, Mattias; Wiklund, Johan

Lumpkin, G. T.; Brigham, Keith H.; Moss, Todd W.

De Massis, Alfredo; Frattini, Federico; Lichtenthaler, Utrich

Cotte, J; Wood, SL

Craig, Justin; Dibrell, Clay

Craig, JBL; Moores, K; Cassar, G

Short, Jeremy C.; Payne, G. Tyge; Brigham, Keith H.; Lumpkin, G. T.; Broberg, J. Christian

McCann, JE; Leon-Guerrero, AY; Haley, JD

Kellermanns, Franz W.; Eddleston, Kimberly A.; Sarathy, Ravi; Murphy, Fran

Zellweger, Thomas; Sieger, Philipp

De Massis, Alfredo; Frattini, Federico; Pizzurno, Emanuele; Cassia, Lucio

Patel, Pankaj C.; Chrisman, James J.

Casillas, Jose C.; Moreno, Ana M.

Munoz-Bullon, Fernando; Sanchez

Bueno, Maria J.

Danes, Sharon M.; Stafford, Kathryn; Loy, Johnben Teik-Cheok

Wagner, Marcus

Koenig, Andreas; Kammerlander, Nadine; Enders, Albrecht

Litz, Reginald A.; Pearson, Allison W. Litchfield, Shanan

Kotlar, Josip; De Massis, Alfredo;

Frattini, Federico; Bianchi, Mattia;

Fang, Hanqing

Chrisman, James J.; Chua, Jess H.; De Massis, Alfredo; Frattini, Federico; Wright, Mike

\begin{tabular}{|c|c|c|c|c|c|}
\hline Journal & Year & $\mathrm{TC}$ & TCIFF & $\begin{array}{l}\text { TCIFF/ } \\
\text { TC }\end{array}$ & $\mathrm{T} 1$ \\
\hline FBR & 2005 & 284 & 53 & $18,7 \%$ & $\mathrm{X}$ \\
\hline FBR & 2007 & 262 & 45 & $17,2 \%$ & 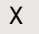 \\
\hline JMS & 2008 & 163 & 23 & $14,1 \%$ & X \\
\hline IMM & 2005 & 131 & 10 & $7,6 \%$ & $x$ \\
\hline JBV & 2011 & 116 & & $0,0 \%$ & \\
\hline ETP & 2012 & 112 & 17 & $15,2 \%$ & \\
\hline JBV & 1996 & 108 & & $0,0 \%$ & 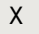 \\
\hline ETP & 2008 & 100 & 23 & $23,0 \%$ & X \\
\hline JBV & 2012 & 96 & 42 & $43,8 \%$ & \\
\hline SBE & 2007 & 94 & & $0,0 \%$ & $\mathrm{X}$ \\
\hline ERD & 2010 & 91 & 14 & $15,4 \%$ & \\
\hline FBR & 2013 & 85 & 52 & $61,2 \%$ & \\
\hline JCR & 2004 & 84 & & $0,0 \%$ & X \\
\hline FBR & 2006 & 84 & 30 & $35,7 \%$ & $x$ \\
\hline FBR & 2006 & 75 & & $0,0 \%$ & $\mathrm{X}$ \\
\hline FBR & 2009 & 75 & & $0,0 \%$ & $x$ \\
\hline JSBM & 2001 & 73 & 15 & $20,5 \%$ & $x$ \\
\hline SBE & 2012 & 73 & 26 & $35,6 \%$ & \\
\hline SBE & 2012 & 62 & 11 & $17,7 \%$ & \\
\hline JSBM & 2015 & 58 & 35 & $60,3 \%$ & \\
\hline SMJ & 2014 & 55 & 18 & $32,7 \%$ & \\
\hline ERD & 2010 & 49 & 6 & $12,2 \%$ & \\
\hline FBR & 2011 & 49 & 23 & $46,9 \%$ & \\
\hline JBR & 2007 & 47 & & $0,0 \%$ & $x$ \\
\hline JBE & 2010 & 47 & 6 & $12,8 \%$ & \\
\hline AMR & 2013 & 47 & & $0,0 \%$ & \\
\hline FBR & 2012 & 45 & 19 & $42,2 \%$ & \\
\hline JPIM & 2013 & 44 & 24 & $54,5 \%$ & \\
\hline JPIN & 2015 & 43 & 21 & $48,8 \%$ & \\
\hline
\end{tabular}

R: rank. TC: total cites, TCIFF: total cites among articles of the IFF dataset. TC/TP: cites per article 
In the initial period, Zahra highlights the most cited articles on this topic. It is worth mentioning that Zahra is an important author who has worked in different disciplines of social sciences, particularly in the field of entrepreneurship. The research by Zahra has been diverse, ranging mainly in the three areas of management and strategy- entrepreneurship, international entrepreneurship, and social entrepreneurship (Audretsch, 2015).

Nordqvist is another important author in T1, contributing two articles, but since the author has also published in $\mathrm{T} 2$, the total number of articles are four, reaching a total number of citations of $\mathrm{TP}=4$ and $\mathrm{TC}=373$.

The two articles published in the initial period, with Wiklund between others authors, are in category of most-cited articles (see Table 3 ).

In 2007, Nordqvist and Wiklund published "Entrepreneurial orientation, risk taking, and performance in family firms" in the journal Family Business Review, co-authored by Naldi and Sjoberg. This is a reference article focusing on risk taking as an important dimension of entrepreneurial orientation and its impact on family firms with 262 citations (Naldi et al., 2007).

It is also necessary to highlight the influence of Craig, with three articles during each period. He coauthored with Dibrell the article "The natural environment, innovation, and firm performance: A comparative study" (Craig \& Dibrell, 2006), and appears in Table 3 as one of the 21 most cited articles on IFF ( $13^{\text {th }}$ position).

In the expansion period, the top rankings are for De Massis with 13 articles and Frattini with 8 articles.

De Massis is the author with best combination of productivity and influence in the context of IFF research. He is an author with high productivity and 339 citations. These authors concentrate all their publications in this period.

The article "Research on Technological Innovation in Family Firms: Present Debates and Future Directions" (De Massis, Frattini \& Lichtenhaler, 2013) with more than 17 citations per year is reflected in Table 3 as one of the 12 most-cited articles on IFF.

In this article, the authors analyze the state of research in technological innovation in the area of FF.

\section{Most Productive Groups of Authors with Significant Research Lines in IFF}

Science is collaboration and it can be understood as a form of scientific social network where scholars share knowledge.

This network can be represented as a graph in which the nodes are scholars and links are specific forms of scientific collaboration between them (Sonnenwald, 2007).

Thus, co-authorship is an indicator of scientific collaboration in which authors publish their research outcomes through writing papers. Whenever scholars publish a co-authored article, they have contributed to an individual coauthorship network, which reveals only those authors that have made direct contributions to the article content.

If individual co-authorship networks are analyzed in aggregate form, this network exhibits interconnected relationships among scholars $(\mathrm{Li}$, Liao, \& Yen, 2013).

Assuming that co-authorship indicates a level of scientific collaboration, we used network analysis to identify authors in a co-authorship network (Noyons, Moed, \& Van Raan, 1999).

We reduced the network focusing on the connections between scholars who had published two or more articles on IFF, and with a minimum of one co-authoring relationships.

Overall, 24 authors meet these restrictions.

The reduced network is represented in a diagram (Figure 2), created with VOSviewer software (version 1.6.9).

This analysis of co-authorships among the most productive authors allows a systematized vision of the main research groups in the IFF field. Focusing on the thematic similarities between the articles by related authors in each cluster, it is possible to categorize the information into themes. In several instances, the themes were identified by analyzing the title, abstract, and keywords of each article. In other cases, an in depth analysis of the article was required.

After identification and content revision, the articles spread among the co-authorship groups are organized into three main research streams. 
Table 4 The most productive authors and cited authors.

\begin{tabular}{|c|c|c|c|c|c|c|c|c|c|c|}
\hline $\mathrm{R}$ & AUTHORS & TC & TP & $\mathrm{TC} / \mathrm{TP}$ & T1P & $\mathrm{T} 1 \mathrm{C}$ & $\mathrm{T} 1 \mathrm{C} / \mathrm{T} 1 \mathrm{P}$ & $\mathrm{T} 2 \mathrm{P}$ & $\mathrm{T} 2 \mathrm{C}$ & $\mathrm{T} 2 \mathrm{C} / \mathrm{T} 2 \mathrm{P}$ \\
\hline 1 & De Massis, A. & 339 & 13 & 26,08 & 0 & 0 & 0,00 & 13 & 339 & 26,08 \\
\hline 2 & Frattini, F. & 269 & 8 & 33,63 & 0 & 0 & 0,00 & 8 & 269 & 33,63 \\
\hline 3 & Craig, Justin B. & 229 & 6 & 38,17 & 3 & 186 & 62,00 & 3 & 43 & 14,33 \\
\hline 4 & Chrisman, James J. & 233 & 5 & 46,60 & 0 & 0 & 0,00 & 5 & 233 & 46,60 \\
\hline 5 & Fang, $\mathrm{H}$. & 88 & 5 & 17,60 & 0 & 0 & 0,00 & 5 & 88 & 17,60 \\
\hline 6 & Kotlar, J. & 84 & 5 & 16,80 & 0 & 0 & 0,00 & 5 & 84 & 16,80 \\
\hline 7 & Nordqvist, M. & 373 & 4 & 93,25 & 2 & 356 & 178,00 & 2 & 17 & 8,50 \\
\hline 8 & Kellermanns, F. W. & 273 & 4 & 68,25 & 1 & 163 & 163,00 & 3 & 110 & 36,67 \\
\hline 9 & Kammerlander, N. & 91 & 4 & 22,75 & 0 & 0 & 0,00 & 4 & 91 & 22,75 \\
\hline 10 & Wright, $M$. & 63 & 4 & 15,75 & 0 & 0 & 0,00 & 4 & 63 & 15,75 \\
\hline 11 & Kraus, S. & 39 & 4 & 9,75 & 0 & 0 & 0,00 & 4 & 39 & 9,75 \\
\hline 12 & Memili, E. & 31 & 4 & 7,75 & 0 & 0 & 0,00 & 4 & 31 & 7,75 \\
\hline 13 & Zellweger, T. & 201 & 3 & 67,00 & 0 & 0 & 0,00 & 3 & 201 & 67,00 \\
\hline 14 & Chua, Jess H. & 158 & 3 & 52,67 & 0 & 0 & 0,00 & 3 & 158 & 52,67 \\
\hline 15 & Dibrell, C. & 113 & 3 & 37,67 & 1 & 84 & 84,00 & 2 & 29 & 14,50 \\
\hline 16 & Uhlaner, L. M. & 52 & 3 & 17,33 & 1 & 4 & 4,00 & 2 & 48 & 24,00 \\
\hline 17 & Matzler, K. & 25 & 3 & 8,33 & 0 & 0 & 0,00 & 3 & 25 & 8,33 \\
\hline 18 & Welsh, Dianne H. B. & 20 & 3 & 6,67 & 0 & 0 & 0,00 & 3 & 20 & 6,67 \\
\hline 19 & Iturralde, T. & 18 & 3 & 6,00 & 0 & 0 & 0,00 & 3 & 18 & 6,00 \\
\hline 20 & Maseda, A. & 18 & 3 & 6,00 & 0 & 0 & 0,00 & 3 & 18 & 6,00 \\
\hline 21 & Sanchez-Famoso, V. & 18 & 3 & 6,00 & 0 & 0 & 0,00 & 3 & 18 & 6,00 \\
\hline 23 & Dieguez-Soto, J. & 6 & 3 & 2,00 & 0 & 0 & 0,00 & 3 & 6 & 2,00 \\
\hline 24 & Calabro, A. & 3 & 3 & 1,00 & 0 & 0 & 0,00 & 3 & 3 & 1,00 \\
\hline 25 & Lopez-Fernandez, M. & 2 & 3 & 0,67 & 0 & 0 & 0,00 & 3 & 2 & 0,67 \\
\hline 22 & Serrano-Bedia, A. & 2 & 3 & 0,67 & 0 & 0 & 0,00 & 3 & 2 & 0,67 \\
\hline 26 & Wiklund, J. & 356 & 2 & 178,00 & 2 & 356 & 178,00 & 0 & 0 & 0,00 \\
\hline 27 & Eddleston, K. A. & 236 & 2 & 118,00 & 1 & 163 & 163,00 & 1 & 73 & 73,00 \\
\hline 28 & Sarathy, R. & 236 & 2 & 118,00 & 1 & 163 & 163,00 & 1 & 73 & 73,00 \\
\hline 29 & Sieger, P. & 178 & 2 & 89,00 & 0 & 0 & 0,00 & 2 & 178 & 89,00 \\
\hline 30 & Brigham, K. H. & 166 & 2 & 83,00 & 1 & 75 & 75,00 & 1 & 91 & 91,00 \\
\hline 31 & Lumpkin, G. T. & 166 & 2 & 83,00 & 1 & 75 & 75,00 & 1 & 91 & 91,00 \\
\hline 32 & Steier, L. & 114 & 2 & 57,00 & 0 & 0 & 0,00 & 2 & 114 & 57,00 \\
\hline 33 & Block, J. H. & 106 & 2 & 53,00 & 0 & 0 & 0,00 & 2 & 106 & 53,00 \\
\hline 34 & Moores, $\mathrm{K}$ & 102 & 2 & 51,00 & 2 & 102 & 51,00 & 0 & 0 & 0,00 \\
\hline 35 & Zahra, SA & 284 & 1 & 284,00 & 1 & 284 & 284,00 & 0 & 0 & 0,00 \\
\hline 36 & Naldi, L. & 262 & 1 & 262,00 & 1 & 262 & 262,00 & 0 & 0 & 0,00 \\
\hline 37 & Sjoberg, K. & 262 & 1 & 262,00 & 1 & 262 & 262,00 & 0 & 0 & 0,00 \\
\hline 38 & Hausman, A & 131 & 1 & 131,00 & 1 & 131 & 131,00 & 0 & 0 & 0,00 \\
\hline 39 & Halter, F. & 116 & 1 & 116,00 & 0 & 0 & 0,00 & 1 & 116 & 116,00 \\
\hline 40 & Rau, S. B. & 112 & 1 & 112,00 & 0 & 0 & 0,00 & 1 & 112 & 112,00 \\
\hline 41 & Boter, H & 108 & 1 & 108,00 & 1 & 108 & 108,00 & 0 & 0 & 0,00 \\
\hline
\end{tabular}


maseda, a

iturralde, $\mathrm{t}$ kammerlander, $\mathrm{n}$

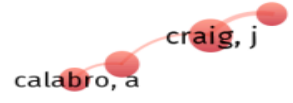

lopez-fernandez, m

serrano-bedia, a

Figure 2. Co-authored research on IFF

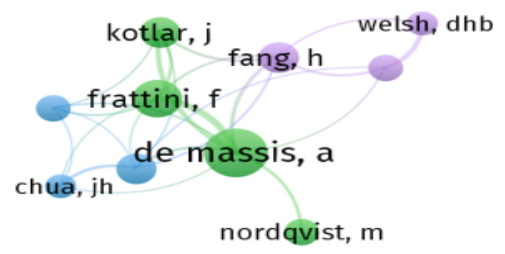

\begin{tabular}{|c|c|c|}
\hline Cluster & AUTHORS & Research Topics \\
\hline & $\begin{array}{l}\text { Craig, J.; Dibrell, C.; Kraus, S.; } \\
\text { Calabro, A. }\end{array}$ & $\begin{array}{l}\text { Internal factors } \\
\text { of IFF }\end{array}$ \\
\hline 2 & $\begin{array}{l}\text { Nordqvist, M.; De Massis, A.; } \\
\text { Frattini, F.; Kotlar, J. }\end{array}$ & $\begin{array}{l}\text { Internal Factors } \\
\text { of IFF, } \\
\text { External Factors } \\
\text { of IFF } \\
\text { Advances in IFF }\end{array}$ \\
\hline 3 & $\begin{array}{l}\text { Chua, J. H.; Chrisman, J.; } \\
\text { Wright, M. }\end{array}$ & $\begin{array}{l}\text { Internal Factors } \\
\text { of IFF }\end{array}$ \\
\hline 4 & $\begin{array}{l}\text { Sanchez-famoso, V.; Iturralde } \\
\text { T.; Maseda, A. }\end{array}$ & $\begin{array}{l}\text { Internal Factors } \\
\text { of IFF } \\
\text { Advances in IFF }\end{array}$ \\
\hline 5 & $\begin{array}{l}\text { Memili, Esra; Fang, Hanqing; } \\
\text { Welsh, Dianne }\end{array}$ & $\begin{array}{l}\text { Internal Factors } \\
\text { of IFF } \\
\text { Advances in IFF }\end{array}$ \\
\hline 6 & $\begin{array}{l}\text { Serrano-Bedia, A., Lopez- } \\
\text { Fernandez, M.; }\end{array}$ & $\begin{array}{l}\text { Internal Factors } \\
\text { of IFF }\end{array}$ \\
\hline 7 & Kammerlander,; Zellweger, & $\begin{array}{l}\text { Internal Factors } \\
\text { of IFF }\end{array}$ \\
\hline
\end{tabular}

Main Research Streams in IFF Coauthorship Groups

In this section, we develop a content overview of each of the three research streams (Table 5), identified from the publications of the coauthorship groups. The three research streams considered are internal factors of IFF, external factors of FF, and advances in IFF.

It is important to emphasize that the same coauthorship group may have developed more than one research stream, and different co-authorship groups may have worked on the same research stream.

\section{Cluster A: Internal Factors of IFF}

The studies in this cluster focus on identifying the internal characteristics of family firms that affect innovation behavior. These investigations draw on resource-based view (RBV) (Craig, Dibrell, \& Garret, 2014; Basco \& Calabro, 2016), upper echelons theory (Craig, Pohjola, Kraus, \& Jensen 2014), stewardship theory (Neubaum, Thomas, Dibrell, \& Craig, 2017), socio-emotional wealth (SEW) (Calabro, Minola, Campopiano, \& Pukall, 2016), and social capital theory (Sanchez-Famoso, Maseda \& Iturralde 2014, 2017; Sanchez-Famoso, Iturralde, \& Maseda, 2015). Using these theories, this article highlights the heterogeneity of family firms and the role of internal attributes in business strategy (Craig \& Dibrell, 2006; Craig, Moores, \& Cassar, 2006). In this sense, each family firm possesses a unique set of internal characteristics such as family culture, noneconomic goals, internal relationships, and board composition, which are acquired and developed over time. These family firms' singularities further determine the degree of efficiency and, therefore, strategic decisions such as involvement in innovation.

Family culture is a possible measure of the firm's organizational resources (Craig et al., 2014). It represents the knowledge accumulated throughout the family history and is related to 
better management of fluent communication, which directly relates to innovation and creativity (Neubaum et al., 2017).

Non-economic goals are indeed related to less investments in R\&D because family members want to protect their SEW, thus avoiding taking innovation risks, which affect the firm's innovations (Calabro et al., 2016).

Internal relationships refer to relationships inside the family firms (Sanchez-Famoso, Maseda \& Iturralde 2014, 2017; Sanchez-Famoso, Iturralde, \& Maseda, 2015). These relationships include not only those between family members but also between non-family members; two different groups that coexist in the majority of family firms (Mitchell, Morse, \& Sharma, 2003; SanchezFamoso et al., 2015). The shared vision of the business, same language, and intensity of the relationships are antecedents of IFF. Ownership and family management (Sanchez-Famoso et al., 2015, Sanchez-Famoso, Maseda \& Iturralde, 2017) play a moderate role between internal relationships and innovation. This is could be attributed to the fact that if more family members are part of the top management team (TMT), the firm's innovation propensity increases; however, according to Lohe and Calabro (2017) conflicts can emerge due to the different perspectives expressed by the TMT members.

Overall, the board has a relationship with the firm's innovation behavior (Lopez-Fernandez, Serrano-Bedia, \& Perez-Perez, 2016). The board's composition (number of family members, nonfamily members, and interlocks) is the main characteristic that could affect strategic decisions (Serrano-Bedia, Lope-Fernandez, \& GarciaPiqueres, 2016). The chief executive officer's (CEO) tenure (Lopez-Fernandez, Serrano-Bedia, \& Palma-Ruiz, 2016) may have less incentive to invest in R\&D in family firms due to SEW protection.

Another internal factor that matters is how the creation of family firms affects innovation (Brunninge, Nordqvist, \& Wiklund, 2007; Zellweger \& Sieger, 2012). In this respect, entrepreneurial behaviors influence both innovation and long-term success (Kammerlander \& Ganter, 2015; Kammerlander, Dessi, Bird, Floris, \& Murru, 2015). If the family firm is created with the main aim of preserving SEW, the firm can continue across generations (Welsh, Memili, Kaciak, \& Al Sadoon, 2014); however, firms can fail in starting or operating new ideas and innovations (Memili, Welsh, \& Kaciak, 2014). In this sense, family support in difficult times is fundamental for continuing with the company (Memili, Fang, \& Welsh, 2015). The authors who focused on this internal aspect of family firms are based in specific theories such as planned behavior theory (Zellweger, Sieger, \& Halter, 2011; Zellweger \& Sieger, 2012) and organizational psychological capital (Memili, Welsh, \& Kaciak, 2014, Memili, Fang \& Welsh, 2015; Welsh, et al., 2014)

\section{Cluster B: External Factors of IFF}

A central finding in the literature is that innovation in family firms depends on external resources. In this sense, IFF is also a process that derives from the strengthening of the family firm's core competences. These resources include not only financial or human capital but also connections with other firms and institutions (Kotlar, De Massis, Fratiini, Bianchi, \& Fang, 2013; Kotlar, Fang, De Massis, \& Frattini, 2014). In a competitive era, success depends on the ability to produce new or improved products and tacit knowledge constitutes the most important basis for innovation-based value creation (Memili, Fang, Chrisman, \& De Massis, 2015). However, it is difficult to exchange a firm's innovation activities over long distances (Chrisman, Fang, Kotlar, \& De Massis, 2015). Therefore, innovation activities are collective achievements that require key roles from numerous entrepreneurs (Memili et al., 2015), rather than an isolated decision within a single firm. External financial availability liberates family firms from the need to generate funds internally by helping them raise capital from external sources at a reasonable cost (Welsh et al., 2014).

\section{Cluster C: Advances in IFF}

In this cluster, advanced research studies on IFF appear. They develop a theory at the important intersection of family firms and innovation (De Massis, Frattini \& Lichtenhaler, 2013). As it is shown that innovation helps family firms to respond effectively to shifts in market dynamism (Chrisman, Chua, De Massis, Frattini, \& Wright, 2015; De Massis, Frattini, Kotlar, Petruzzelli, \& Wright, 2016), articles in this cluster call for some research streams to study why innovation makes it possible to recognize market dynamism (De Massis, Di Minin, \& Frattini, 2015). The theories used in this research stream are agency, RBV, grounded, and SEW. The singularities of family firms may be important precursors of the innovation. They call for undertaking research considering the essence of focus, which explains why there is no common result on how to make innovation happen in family firms. They agree that there is a need to address how family firms manage radical innovations and explore disruptive innovation (Brunninge et al., 2007; Casprini, De Massis, Di Minin, Frattini, \& Piccaluga, 2017; De Massis, Frattini \& lichtenhaler, 2013). Thus, 
building on this, it would be interesting to explore the relations between ambidexterity and new product development management associated with loose-coupled partners and complementors, and the limits and risks of a pivot strategy. On the other hand, there is a need to focus on the critical capabilities that are important for innovation, such as dynamic and integration capability (De Massis, Frattini, Pizzurno, \& Cassia, 2015; Fitz-Koch \& Nordqvist, 2017). These streams of research are expected to not only advance theoretical understanding but also improve how family firms manage and organize innovation.

\section{Conclusion}

This study examined the scientific research in IFF between 1994 and 2017, based on publications available in the WoS database. The evolution in the field of study shows that the topic's overall tendency has been ascendant, especially since 2009. Thus, it is possible to distinguish two different periods: the initial period, prior to 2009 (T1), and the expansion period, after the year 2009 (T2).

Although this study is not the first attempt to conduct a comprehensive and systematic review of academic IFF research, this article adds a bibliometric perspective to the IFF research topic, providing a synthesis and organization of existing knowledge in this research stream. Thus, this article provides a broad view of the research in this field and attempts to contribute to the increased generation of literature on IFF and, in doing so, facilitates the work of academics, students, consultants, family business entrepreneurs and sociologists. According to the study's limitations, the information presented in this study is expected to be complementary and informative to other bibliographic literature reviews. Second, the dataset was gathered exclusively from the WoS database. Thus, data from other sources (e.g., Scopus and Google Scholar) were not used. Finally, co-authorship analysis has been used to identify the main research streams instead of other mapping techniques, such as co-citation and citation, to complete the bibliometric overview.

\section{References}

Arregle, J. L., Hitt, M. A., Sirmon, D. G., \& Very, P. (2007). The development of organizational social capital: Attributes of family firms. Journal of Management Studies, 44(1), 73-95.

Audretsch, D. (2015). Shaker a. Zahra: Pioneering entrepreneurship scholar. Small Business Economics, 44(4), 721-725.

Baier-Fuentes, H., Merigó, J. M., Amoros, J. E., \& Gaviria-Marin, M. (2018). International entrepreneurship: A bibliometric overview. International Entrepreneurship and Management Journal, https://doi.org/10.1007/s11365-017-0487
Basco, R., \& Calabro, A. (2016). Open innovation search strategies in family and non-family SMEs: Evidence from a natural resource-based cluster in chile. Academia Revista Latinoamericana De Administración, 29(3), 279-302.

Bjork, S., Offer, A., \& Söderberg, G. (2014). Time series citation data: The nobel prize in economics. Scientometrics, 98(1), 185-196.

Block, J. (2010). Family management, family ownership, and downsizing: Evidence from S\&P 500 firms. Family Business Review, 23(2), 109-130.

Brunninge, O., Nordqvist, M., \& Wiklund, J. (2007). Corporate governance and strategic change in SMEs: The effects of ownership, board composition and top management teams. Small Business Economics, 29(3), 295-308.

Calabro, A., Minola, T., Campopiano, G., \& Pukall, T. J. (2016). Turnin innovativeness into domestic and international corporate venturing: The moderating effect of high family ownership and influence. European Journal of International Management, 10(5), 505-533.

Calabro, A., Vecchiarini, M., Gast, J., Campopiano, G., De Massis, A., \& Kraus, S. (2018). Innovation in family firms: A systematic literature review and guidance for future research. International Journal of Management Reviews, DOI: 10.1111/ijmr. 12192

Callon, M., Courtial, J. P., \& Laville, F. (1991). Coword analysis as a tool for describing the network of interactions between basic and technological research: The case of polymer chemsitry. Scientometrics, 22(1), 155-205.

Carvalho, M., Fleury, A. C., \& Lopes, A. P. (2013). An overview of the literature on technology roadmapping (TRM): Contributions and trends. Technological Forecasting and Social Change, 80(7), 1418-1437.

Casprini, E., De Massis, A., Di Minin, A., Frattini, F., \& Piccaluga, A. (2017). How family firms execute open innovation strategies: The Loccioni case. Journal of Knowledge Management, 21(6), 14591485.

Chirico, F., \& Salvato, C. (2016). Knowledge internalization and product development in family firms: When relational and affective factors matters. Entrepreneurship Theory and Practice, 40(1), 201-229.

Chrisman, J. J., Chua, J. H., De Massis, A., Frattini, F., \& Wright, M. (2015). The ability and willingness paradox in family firm innovation. Journal of Product Innovation Management, 32(3), 310-318.

Chrisman, J. J., Chua, J. H., \& Steier, L. P. (2005). Resources and consequences of distinctive familiness: An introduction. Entrepreneurship Theory and Practice, 29(3), 237-247.

Chrisman, J. J., Fang, H., Kotlar, J., \& De Massis, A. (2015). A note on family influence and the adoption of discontinuous technologies in family firms. Journal of Product Innovation Management, 32(3), 384-388.

Chua, J. H., Chrisman, J. J., Steier, L. P., \& Rau, S. B. (2012). Sources of heterogeneity in family firms: An introduction. Entrepreneurship Theory and Practice, 36(6), 1103-1113.

Cobo, M. J., Lopez-Herrera, A. G., Herrera-Viedma, E., \& Herrera, F. (2011). Sciencience mapping software tools: Review, analysis, and cooperative study among tools. Journal of the American Society for Information Science and Technology, 2011(7), 1382-1402. 
Cobo, M. J., Martinez, M. A., Gutierrez-Salcedo, M., Fujita, H., \& Herrera-Viedma, E. (2015). 25 years at knowledge-based systems: A bibliometric analysis. Knowledge-Based Systems, 80(1), 3-13.

Craig, J. B., \& Dibrell, C. (2006). The natural environment, innovation, and firm performance: A comparative study. Family Business Review, 19(4), 275-288.

Craig, J. B., Dibrell, C., \& Garrett, R. (2014). Examining relationships among family influence, family culture, flexible planning systems, innovativeness and firm performance. Journal of Family Business Strategy, 5(3), 229-238.

Craig, J. B., Moores, K., \& Cassar, G. (2006). A 10 year longitudinal investigation of strategy, systems, and environment on innovation output in family and non-family firms. Family Business Review, 19(2), 169-169.

Craig, J. B., Pohjola, M., Kraus, S., \& Jensen, S. H. (2014). Exploring relationships among proactiveness, risk-taking and innovation output in family and non-family firms. Creativity and Innovation Management, 23(2), 199-210.

Credit Suisse - Research Institute. (2018). The CS family 1000 in 2018. Zurich: Credit Suisse Group A6

Cruz, C., \& Nordqvist, M. (2012). Entrepreneurial orientation in family firms: A generational perspective. Small Business Economics, 38(1), 3349.

D'Amato, A. (2017). Do women perform better in family firms? Exploring the moderating role of family firm's status. International Journal of Wine Business Research, 29(3), 299-315.

De Massis, A., Di Minin, A., \& Frattini, F. (2015). Family-driven innovation: Resolving the paradox in family firms. Califronia Management Review, 58(1), 5-19.

De Massis, A., Frattini, F., Kotlar, J., Petruzzelli, A. M., \& Wright, M. (2016). Innovation through tradiion: Lessons from innovative family businesses and directions for future research. Academy Management Perspectives, 30(1), 93-116.

De Massis, A., Frattini, F., \& Lichtenthaler, U. (2013). Research on technological innovation in family firms: Present debates and future directions. Family Business Review, 26(1), 10-31.

De Massis, A., Frattini, F., Pizzurno, E., \& Cassia, L. (2015). Product innovation in family versus nonfamily firms: An exploratory analysis. Journal of Small Business Management, 53(1), 1-36.

De Massis, A., Sharma, P., Chua, J. H., \& Chrisman, J. J. (2012). Family business studies: An annotated bibliography. Cheltenham: Edward Elgar.

Debicki, B. J., Matherne III, C. F., Kellermanns, F. W., \& Chrisman, J. J. (2009). Family business research in the new millennium. An overview of the who, the where, the what, and the why. Family Business Review, 22(2), 151-166.

Dibrell, C., \& Moeller, M. (2011). The impact of a service-dominant focus strategy and stewardship culture on organizational innovativeness in familyowned businesses. Journal of Family Business Strategy, 2(1), 43-51.
Drakopoulou Dodd, S., \& Anderson, A. (2013). Being in time and the family owned firm. Scandinavian Journal of Management, 29(1), 35-47.

Eddleston, K. A., Kellermanns, F. W., \& Sarathy, R. (2008). Resource configuration in family firms: Linking resources, strategic planning and technological opportunities to performance. Journal of Management Studies, 45(1), 26-50.

Feranita, F., Kotlar, J., \& De Massis, A. (2017). Collaborative innovation in family firms: Past research, current debates and agenda for future research. Journal of Family Business Strategy, 8(3), 137-156.

Fitz-Koch, S., \& Nordqvist, M. (2017). The reciprocal relationship of innovation capabilities and socioemotional wealth in a family firm. Journal of Small Business Management, 55(4), 547-570.

Gedajlovic, E. R., \& Carney, M. (2010). Markets, hierarchies, and families: Toward a transaction cost theory of the family firm. Entrepreneurship Theory and Practice, 34(6), 1145-1172.

Gersick, K. F., Davis, J. A., Hampton, M. A., \& Lansberg, I. (1997). Generation to generation: Life cycles of the family business. Cambridge: Harvard Business School Press.

Gilinsky, A., Santini, C., Lazzeretti, L., \& Eyler, R. (2008). Desperately seeking serendipity. Exploring the impact of country location on innovation in the wine industry. International Journal of Wine Business Research, 20(4), 302-320.

Gomez-Mejia, L. R., Haynes, K. T., Nunez-Nickel, M., Jacobson, K. J., \& Monayo-Fuentes, J. (2007). Socioemotional wealth and business risks in familycontrolled firms: Evidence from Spanish olive oil mills. Administrative Science Quartely, 52(1), 106137.

Habbershon, T. G., Williams, M. L., \& MacMillan, I. C. (2003). A unified systems perspective of family firm performance. Journal of Business Venturing, 18(4), $451-465$.

Kammerlander, N., Dessi, C., Bird, M., Floris, M., \& Murru, A. (2015). The impact of shared stories on family firm innovation: A multicase study. Family Business Review, 28(4), 332-354.

Kammerlander, N., \& Ganter, M. (2015). An attention-based view of family firm adaptation to discontinuous technological change: Exploring the role of family CEOs' noneconomic goals. Journal of Product Innovation Management, 32(3), 361-383.

Kotlar, J., De Massis, A., Frattini, F., Bianchi, M., \& Fang, H. (2013). Technology acquisition in family and nonfamily firms: A longitudinal analysis of Spanish manufacturing firms. Journal of Product Innovation Management, 30(6), 1073-1088.

Kotlar, J., Fang, H., De Massis, A., \& Frattini, F. (2014). Profitability goals, control goals, and the R\&D investment decisions of family and nonfamily firms. Journal of Product Innovation Management, 31(6), 1128-1145.

Li, E., Liao, C. H., \& Yen, H. R. (2013). Co-authorship networks and research impact: A social capital perspective. Research Policy, 42(9), 1515-1530.

Llach, J., \& Nordqvist, M. (2010). Innovation in family and non-family businesses: A resource perspective.

Aparicio, G., Iturralde T., Sanchez-Famoso, V. (2019). Innovation in family firms: a holistic bibliometric overview of the research field. European Journal of Family Business, 9(2), 71-84. 
International Journal of Entrepreneurial Venturing, 2(3), 381-399.

Lohe, F. W., \& Calabro, A. (2017). Please do not disturb! Differentiating board tasks in family and non-family firms during financial distress. Scandinavian Journal of Management, 33(1), 36-49.

Lopez-Fernandez, M. C., Serrano-Bedia, A. M., \& Palma-Ruiz, M. (2016). What hampers innovation in mexican family fims? Academia Revista Latinoamericana De Administración, 29(3), 255-278.

Lopez-Fernandez, M. C., Serrano-Bedia, A. M., \& Perez-Perez, M. (2016). Entrepreneurship and family firm research: A bibliometric analysis of an emerging field. Journal of Small Business Management, 54(2), 622-639.

Memili, E., Fang, H., Chrisman, J. J., \& De Massis, A. (2015). The impact of small-and medium-sized family firms on economic growth. Small Business Economics, 45(4), 771-785.

Memili, E., Fang, H., \& Welsh, D. H. B. (2015). Value creation and value appropriation in innovation process in publicly-traded family firms. Management Decision, 53(9), 1921-1952.

Memili, E., Welsh, D. H. B., \& Kaciak, E. (2014). Organizational psychological capital of family franchise firms through the lens of the leadermember exchange theory. Journal of Leathership \& Organizational Studies, 21(2), 200-209.

Merigó, J. M., \& Yang, J. (2017). A bibliometric analysis of operations research and management science. Omega, 73(1), 37-48.

Miller, D., \& Le Breton-Miller, I. (2014). Deconstructing socioemotional wealth. Entrepreneurship Theory and Practice, 38(4), 713720.

Mitchell, R. K., Morse, E. A., \& Sharma, P. (2003). The transacting cognitions of nonfamily employees in the family businesses setting. Journal of Business Venturing, 18(4), 533-551.

Murgado-Armenteros, E. M., Gutierrez-Salcedo, M., Torres-Ruiz, F. J., \& Cobo, M. J. (2015). Analysing the conceptual evolution of qualitative marketing research through science mapping analysis. Scientometrics, 102(1), 519-557.

Naldi, L., Nordqvist, M., Sjöberg, K., \& Wiklund, J. (2007). Entrepreneurial orientation, risk taking, and performance in family firms. Family Business Review, 20(1), 33-47.

Neubaum, D. O., Thomas, C. H., Dibrell, C., \& Craig, J. B. (2017). Stewardship climate scale: An assessment of reliability and validity. Family Business Review, 30(1), 37-60.

Nordqvist, M., \& Melin, L. (2010). The promise of the strategy as practice perspective for family business strategy research. Journal of Family Business Strategy, 1(1), 15-25.

Noyons, E. C., Moed, H. F., \& Van Raan, A. F. (1999). Integrating research performance analysis and science mapping. Scientometrics, 46(3), 591-604.

Pearson, A. W., Carr, J. C., \& Shaw, J. C. (2008). Toward a theory of familiness: A social capital perspective. Entrepreneurship Theory and Practice, 32(6), 949-969.

PwC Global Family Business Survey. (2018). The values effect. How to build a lasting competitive advantage through your values and purpose in a digital age. Retrieved from www.pwc.com/fambizsurvey2018

Sanchez-Famoso, V., Akhter, N., Iturralde, T., Chirico, F., \& Maseda, A. (2015). Is non-family social capital also (or especially) important for family firm performance? Human Relations, 68(11), 1713-1743.

Sanchez-Famoso, V., Iturralde, T., \& Maseda, A. (2015). The influence of family and non-family social capital on firm innovation: Exploring the role of family ownership. European Journal of International Management, 9(2), 240-262.

Sanchez-Famoso, V., Maseda, A., \& Iturralde, T. (2014). The role of internal social capital in organizational innovation. An empirical study of family firms. European Management Journal, 32(6), 950-962.

Sanchez-Famoso, V., Maseda, A., \& Iturralde, T. (2017). Family involvement in top management team: Impact on relationships between internal social capital and innovation. Journal of Management \& Organization, 23(1), 136-162.

Schulze, W. S., Lubatkin, M., Dino, R. D., \& Buchholtz, A. K. (2001). Agency relationships in family firms. Organization Science, 12(2), 99-116.

Schulze, W. S., Lubatkin, M., \& Dino, R. N. (2003). Towads a theory of agency and altruism in family firms. Journal of Business Venturing, 18(4), 473490.

Serrano-Bedia, A. M., Lopez-Fernandez, M. C., \& Garcia-Piqueres, G. (2016). Analysis of the relationship between sources of knowledge and innovation performance in family firms. Innovation, 18(4), 489-512.

Sharma, P. (2004). An overview of the field of family business studies: Current status and directions for the future. Family Business Review, 17(1), 1-36.

Sirmon, D. G., Arregle, J. L., Hitt, M. A., \& Webb, J. $W$. (2008). The role of family influence in firms strategic response to competitive threat. Entrepreneurship Theory and Practice, 32(6), 979998.

Sonnenwald, D. H. (2007). Scientific collaboration. Annual Review of Information Science and Technology, 41(1), 643-681.

Souder, W. E., \& Thomas, R. J. (1994). Significant issues for the future of product innovation. Journal of Product Innovation Management, 11(4), 344-353.

Welsh, D. H. B., Memili, E., Kaciak, E., \& Al Sadoon, A. (2014). Saudi women entrepreneurs: A growing economic segment. Journal of Business Research, 67(5), 758-762.

Wernerfelt, B. (1995). The resource-based view of the firm: Ten years after. Strategic Management Journal, 16(3), 171-174.

Zahra, S. A. (2005). Entrepreneurial risk taking in family firms. Family Business Review, 18(1), 23-40.

Zahra, S. A., Hayton, J. C., \& Salvato, C. (2004). Entrepreneurship in family vs. non-family firms: A resource-based analysis of the effect of organizational culture. Entrepreneurship Theory and Practice, 28(4), 363-381.

Zellweger, T., \& Sieger, P. (2012). Entrepreneurial orientation in long-lived family firms. Small Business Economics, 38(1), 67-84.

Zellweger, T., Sieger, P., \& Halter, F. (2011). Should I stay or should I go? Career choice intentions of students with family business background. Journal of Business Venturing, 26(5), 521-536.

Zupic, I., \& Carter, T. (2015). Bibliometric methods in management organization. Organizational Research Methods, 18(3), 429-472. 